\title{
Crown size and transplant type on the strawberry yield
}

\author{
Carine $\mathrm{Cocco}^{1}$, Jerônimo Luiz Andriolo*, Francieli Lima Cardoso ${ }^{3}$, Ligia Erpen ${ }^{3}$, Odair José \\ Schmitt ${ }^{3}$ \\ ${ }^{1}$ UFSM/CCR - Programa de Pós-Graduação em Agronomia. \\ ${ }^{2}$ UFSM/CCR - Depto. de Fitotecnia, Av. Roraima, 1000 - $97105-900$ - Santa Maria, RS - Brasil. \\ ${ }^{3} U F S M / C C R$ - Graduando em Agronomia. \\ *Corresponding author <jeronimo@pq.cnpq.br> \\ Edited by: Edmilson José Ambrosano
}

\begin{abstract}
Strawberry (Fragaria $x$ ananassa D.) yield is affected by vigor of transplants. Those young and vigorous at planting lead to plants reaching higher vegetative growth and fruit yield than weak or old ones. This study aimed at determining plant growth, development, and fruit yield of the strawberry plant from bare root and plug transplants with different crown diameters. Bare root transplants were produced by rooting stolons and plug transplants from runner tips collected and rooted in a substrate growing bed. Three classes of crown diameters were compared in a $2 \times 3$ factorial and randomized block experimental design, with four replications, 16 plants per plot and a density of 6.6 plants $\mathrm{m}^{-2}$. For bare root transplants, crown diameters were between 3.0 and $5.0 \mathrm{~mm}$ (class 1 ); 5.1 and $8.0 \mathrm{~mm}$ (class 2 ) and greater than $8.1 \mathrm{~mm}$ (class 3). For plug transplants, runner tips were screened between 2.0 and $3.9 \mathrm{~mm}$ (class 1); 4.0 and $5.5 \mathrm{~mm}$ (class 2) and 5.6 to $7.0 \mathrm{~mm}$ (class 3). Transplants of both types were planted at April 16 ${ }^{\text {th }}$, 2008, and at this date, crown diameter, shoot and root dry mass and number of leaves were higher in all classes of plug transplants. Ripe fruits were harvested from June $15^{\text {th }}$ to November $7^{\text {th }}, 2008$, and fresh fruit yield was determined. Plant growth and development were determined at last harvest. Higher growth, development and fruit yield were obtained in plants from plug transplants. For bare root transplants, crown diameters higher than $5.1 \mathrm{~mm}$ can be used while for plug transplants the crown diameter of runner tips does not affect plant growth and fruit yield.
\end{abstract}

Keywords: Fragaria $x$ ananassa Duch., propagation, plug plants, bare root transplants, transplants vigor

\section{Introduction}

In Brazil, commercial strawberry (Fragaria x ananassa D.) crops are established with bare root transplants. Some of them are produced locally in soils that are infected by pathogens. The use of fumigants for soil disinfestations is nowadays restricted. As a consequence, vigor is low and growers import yearly from Argentina and Chile more than $80 \%$ of transplants they need for planting their crops (Oliveira et al., 2005). They are produced in Patagonia region, shipped to Southern Brazil by trucks and local shipment to growers is accomplished by flatbed trucks in later summer, whiteout any refrigeration. They are planted several weeks after dug from the soil and many die as a consequence of high temperatures and unfavorable environmental conditions during shipping. A search for new methods for producing high vigor transplants is an urgent task for improving yield of this crop in Brazil.

The crown diameter is the main variable that has been used to determine the vigor of strawberry transplants. A crown diameter higher than $8.0 \mathrm{~mm}$ has been considered as good vigor indicator (Hochmuth et al., 2001). However, in plug plants the crown diameter is related with the physiological age. Runner tips emitted in early spring can reach in summer crown diameters higher than those grown later. In older transplants a great proportion of the root system is inactive for water and nutrient uptake, leading to low plant survival after planting (Nicola, 1998). In plug transplants, runner tips are rooted in few weeks after harvesting from the stock plant.
In these plants, larger crowns indicate higher vigor and faster initial growth, which allows earlier and higher fruit yield (Bish et al., 2002; Giménez et al., 2009). Runner tips in the crown diameter range between 2 and $5 \mathrm{~mm}$ have been considered for production of plug transplants of high vigor (Durner et al., 2002). Reports on the relation of crown diameter with plant growth, development and fruit yield are scarce in the literature.

This study aimed at determining growth, development and fruit yield of strawberry plants from bare root and plug plants with different crown diameters.

\section{Materials and Methods}

The field experiment was conducted in 2008 in Santa

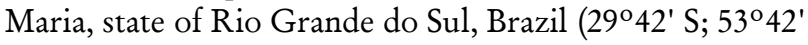
W $-95 \mathrm{~m})$. The climate is subtropical humid by the Köppen's classification, with monthly average temperatures between $3^{\circ} \mathrm{C}$ and $22^{\circ} \mathrm{C}$ and average annual rainfall around $1769 \mathrm{~mm}$ (Moreno, 1961).

The strawberry cultivar Arazá (from Uruguay) was used. It is a short-day, intermediate vigour and early yield cultivar, derived from a cross between selections Uruguayan A07.04 (Oso Grande $\times$ Sweet Charlie) and C01.05 (Addie $\times$ Sweet Charlie) (Giménez et al., 2003). Explants of this cultivar were extracted from the clonal garden at same institution in Santa Maria, RS and multiplied in vitro. After four successive multiplications in the laboratory, they were acclimatized from August $10^{\text {th }}$ to September $13^{\text {th }}, 2007$, in a polyethylene 
greenhouse (Giménez et al., 2008b). After acclimatization, they were planted as stock plants in a closed soilless growing system using sand as a $0.015 \mathrm{~m}$ thick rooting bed. A plant density of 1 plant $\mathrm{m}^{-2}$ was used (Giménez et al., 2008a; 2008b). Water and nutrients were daily delivered by fertigation, using the nutrient solution adjusted by Giménez et al., (2008b), in mmol L-1 : $10.6 \mathrm{NO}_{3}^{-} ; 0.43 \mathrm{NH}_{4}^{+} ; 2 \mathrm{H}_{2} \mathrm{PO}_{4}^{-}$ ; $6.15 \mathrm{~K}^{+} ; 3.0 \mathrm{Ca}^{2+} ; 1 \mathrm{Mg}^{2+}$ and $1 \mathrm{SO}_{4}^{2-}$, and in $\mathrm{mg} \mathrm{L}^{-1}: 0.03$ $\mathrm{Mo} ; 0.42 \mathrm{~B} ; 0.06 \mathrm{Cu} ; 0.50 \mathrm{Mn} ; 0.22 \mathrm{Zn}$ and 1.0 Fe. The $\mathrm{pH}$ and electrical conductivity were maintained between 5.5 and 6.5 and between 1.4 and $1.5 \mathrm{dS} \mathrm{m}^{-1}$. For plug transplant production, runner tips were harvested from stock plants at February $27^{\text {th }}, 2008$ and screened in three crown diameter classes: from 2.0 to $3.9 \mathrm{~mm}$ (class 1); 4.0 to $5.5 \mathrm{~mm}$ (class 2) and 5.6 to $7.0 \mathrm{~mm}$ (class 3) (Durner et al.; 2002; Giménez et al., 2009). Runner tips of different classes were planted in separate rooting beds filled with the commercial substrate to the base of Vermiculite plus pines bark, in a density of 562 runners $\mathrm{m}^{-2}$. In the $1^{\text {st }}$ week after planting, tips were $50 \%$ shaded and sprinkler irrigated eight times a day for $5 \mathrm{~min}$. In the next six weeks, they were daily fertigated as done for the stock plants. Plug transplants were considered ready for planting 48 days after harvesting runner tips, bearing five trifoliate leaves (length $>10 \mathrm{~mm}$ ) on average. Bare root transplants were produced by rooting the stolons emitted by the stock plants in the soilless growing system filled with a commercial substrate, without cutting it from the stock plant (Giménez, 2008a).

Plug and bare root transplants were dug from the rooting bed at April $15^{\text {th }}, 2008$. Older leaves were removed, keeping only the three younger ones. Trimming was not made in plug transplants. Care was taken to dig them with the substrate attached to the root system. For bare root transplants, roots longer than $10 \mathrm{~cm}$ were cut off. They were screened in three crown diameter classes: from 3.0 to $5.0 \mathrm{~mm}$ (class 1); 5.1 to $8.0 \mathrm{~mm}$ (class 2) and higher than $8.0 \mathrm{~mm}$ (class 3 ) (Santos and Medeiros, 2003). A sample of four plants in each plug and bare root classes was used for dry mass determination after drying at $65^{\circ} \mathrm{C}$ until constant mass was recorded. Planting was done in the field at April $16^{\text {th }}, 2008$, on $1.1 \mathrm{~m}$ width polyethylene mulched raised beds, in a plant density of 6.6 plants $\mathrm{m}^{-2}(0.40 \mathrm{~m} \times 0.40 \mathrm{~m})$, covered by low $100 \mu \mathrm{m}$ polyethylene tunnels of $0.70 \mathrm{~m}$ height. In sunny days, tunnels were daily opened at sunrise and closed at sunset while in cloudy or rainy days they remained closed. Fer- tilization, irrigation and other cropping practices were done as reported by Santos and Medeiros (2003). Two types of transplants and three crown diameter classes were compared as treatments, in a $2 \times 3$ factorial scheme. A randomized block design was used, with four replications and 16 plants per plot $\left(2.6 \mathrm{~m}^{-2}\right)$.

Number of days from planting to the beginning of flowering and to the first fruit harvest was recorded. Beginning of flowering was considered when $50 \%$ of plants in the plot had at least one flower at anthesis. Ripe fruits with the epidermis 100\% red identified as stage 87 (Meier et al., 1994) were harvested and weighted twice a week. They were counted, weighted and screened in marketable yield, with fresh mass upper than $10 \mathrm{~g}$, and unmarketable yield, with fresh mass below than $10 \mathrm{~g}$. Fruit yield from the first harvest at June $15^{\text {th }}$ to September $30^{\text {th }}, 2008$, was considered as early production and to November $7^{\text {th }}, 2008$, as total production. The experiment was ended at the last date, when four plants of each treatment were dug from the soil. The crown diameter, number of crowns and number of leaves were counted and dry mass of shoot and roots was determined after drying at of $65^{\circ} \mathrm{C}$ until constant mass was recorded.

The fulfillment of assumptions of the mathematical model for analysis of variance was verified by the error normality test. The variables number of fruits, leaves and crowns were transformed using the expression $(x+0.05)^{0.5}$. All variables were submitted to analysis of variance and the significance of differences among means was determined by the Tukey's test $(p<0.05)$.

\section{Results and Discussion}

At planting, crown diameter and shoot dry mass were higher in plug than in bare root transplants (Table 1). Differences were of $30 \%$ in crown diameter and $42.6 \%$ in shoot dry mass. However, root dry mass was $21.5 \%$ higher in bare root transplants. At the end of the experiment, all variables were higher in plants from plug transplants. Strong differences of about $130 \%$ in shoot dry mass, $103 \%$ in root dry mass and $55 \%$ in number of crowns were recorded (Table 1). These variables, in bare root and plug plants, did not differ among classes of crown diameter at the end of experiment $(p>0.05)$.

Differences were recorded among crown diameter classes in bare root transplants at planting. Crown diameter, shoot and

Table 1 - Average crown diameter (CD), shoot dry mass (SDM) and root dry mass (RDM) of bare root and plug plant strawberry at planting and average number of leaves (NL), crown diameter $(\mathrm{CD})$, shoot dry mass $(\mathrm{SDM})$, root dry mass $(\mathrm{RDM})$ and number of crowns (NC) of plants at the end of the experiment.

\begin{tabular}{|c|c|c|c|c|c|c|c|c|}
\hline \multirow{2}{*}{ Transplant type } & \multicolumn{3}{|c|}{ Planting } & \multicolumn{5}{|c|}{ End of the experiment } \\
\hline & $\mathrm{CD}$ & SDM & $\mathrm{RDM}$ & $\mathrm{NL}$ & $\mathrm{CD}$ & SDM & $\mathrm{RDM}$ & $\mathrm{NC}$ \\
\hline & $\mathrm{mm}$ & \multicolumn{2}{|c|}{-.------ g per plant -.---.-- } & & $\mathrm{mm}$ & \multicolumn{2}{|c|}{------ g per plant --- } & \\
\hline Bare root & $6.6 b^{*}$ & $0.68 \mathrm{~b}$ & $0.51 \mathrm{a}$ & $20 \mathrm{~b}$ & $13.2 \mathrm{~b}$ & $7.66 \mathrm{~b}$ & $2.07 \mathrm{~b}$ & $5.4 \mathrm{~b}$ \\
\hline Plug plant & $8.6 \mathrm{a}$ & $0.97 \mathrm{a}$ & $0.40 \mathrm{~b}$ & $36 \mathrm{a}$ & $15.2 \mathrm{a}$ & $17.65 \mathrm{a}$ & $4.20 \mathrm{a}$ & $8.4 \mathrm{a}$ \\
\hline CV \% & 11 & 25 & 17 & 12 & 10 & 16 & 20 & 18.5 \\
\hline
\end{tabular}

"Means followed by same letter in column do not differ (Tukey, $p<0.05$ ). 
root dry mass were higher in class 3 bare root transplants (crown diameter $>8 \mathrm{~mm}$ ) (Table 2). Lower values were in class 1 (3-5 $\mathrm{mm}$ crown diameter). In plug transplants, crown diameter and root dry mass did not differ among classes, with average values of $8.6 \mathrm{~mm}$ and $0.40 \mathrm{~g}$ per transplant, respectively. Shoot dry mass was higher in class 3 plug transplants (Table 2).

Plant survival after planting and number of days until onset of flowering and fruit harvest differed $(p>0.05)$ on

Table 2 - Crown diameter (CD), shoot dry mass (SDM) and root dry mass $(\mathrm{RDM})$ of bare root and plug plants classes at planting.

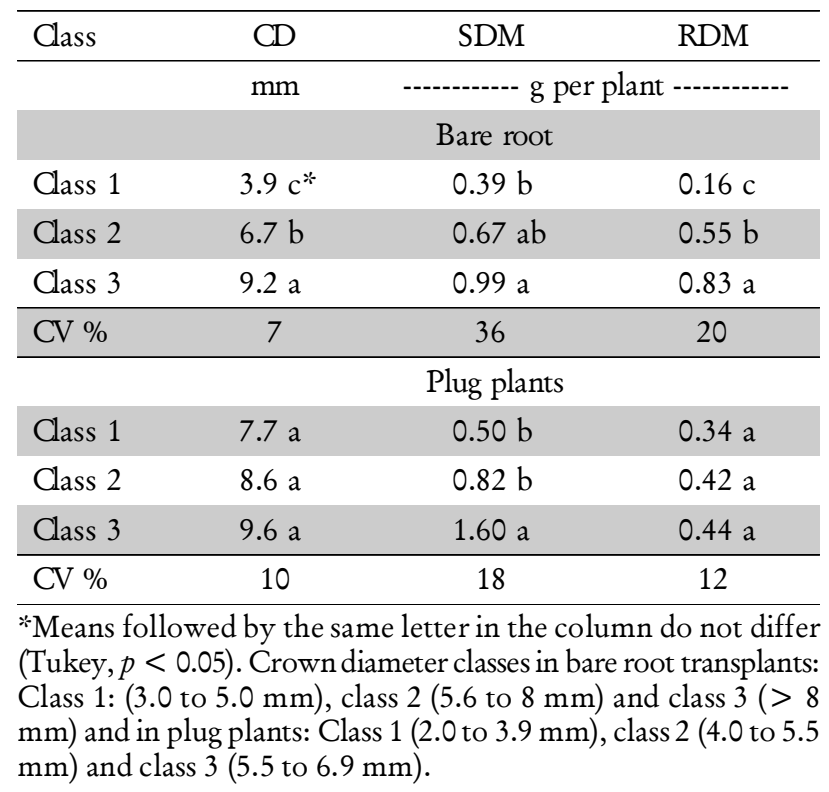

plants from the two transplant types. Plant survival was $98.4 \%$ on plug plant and only $67.4 \%$ on bare root plants. Among classes it was $63.1 \%$ on class 1 bare root plants, not differing from class 2 and 3, with the average 73.4 and $65.6 \%$ of survival. The average initial flowering started at 65 days after planting on bare root transplants, while on plug transplants it was at 48 days. Initial fruit harvesting was at 80 and 72 days after planting for bare root and for plug transplants respectively.

Early and total fruit yield were $89.6 \%$ and $67.1 \%$ higher, respectively, in plants from plug transplants (Table 3). Differences were associated to the number of fruits per plant, being $84.7 \%$ in early and $58.1 \%$ higher in total fruit yield. The average fruit weight did not differ between types and among classes of plants (data not shown). Early fruit yield on plants from bare root transplants were lower on class 1 for number and fresh mass of fruits (Table 3). Values on plants from classes 2 and 3 did not differ. Similar effects were found in total fruit yield, although number of fruits per plant did not differ among treatments. In plants from plug transplants, no differences were found in early and total fruit yield among the three crown diameter classes (Table $3)$.

Strawberry fruit yield was influenced by the type of transplant and also by its vigor, identified by the crown diameter. Despite intensive irrigation in first days, $32.6 \%$ of bare root transplants died after planting and this finding was similar to data reported in the literature (Antunes and Duarte Filho, 2005; Durner et al., 2002). They have to be replaced, delaying plant growth and development, leading to bad crop stand and lower early and total fruit yield. This enormous loss of transplants at planting is a consequence of unfavor-

Table 3 - Number and fresh mass of fruit in early and total yield of strawberry plants from bare root and plug transplants with different crown diameter classes.

\begin{tabular}{|c|c|c|c|c|}
\hline \multirow{2}{*}{ Class } & \multicolumn{2}{|c|}{ Early fruit yield } & \multicolumn{2}{|c|}{ Total fruit yield } \\
\hline & Fruit number & Fresh mass & Fruit number & Fresh mass \\
\hline & & g per plant & & g per plant \\
\hline Bare root & $14.4 b^{*}$ & $192.4 \mathrm{~b}$ & $25.8 \mathrm{~b}$ & $312.4 \mathrm{~b}$ \\
\hline Plug & $26.6 \mathrm{a}$ & $364.8 \mathrm{a}$ & $40.8 \mathrm{a}$ & $522.1 \mathrm{a}$ \\
\hline \multirow[t]{2}{*}{ CV \% } & 15 & 16 & 11 & 14 \\
\hline & \multicolumn{4}{|c|}{ Bare root } \\
\hline Class 1 & $13.5 b^{*}$ & $168.5 \mathrm{~b}$ & $24.2 \mathrm{a}$ & $278.6 \mathrm{~b}$ \\
\hline Class 2 & $15.3 \mathrm{a}$ & $224.3 \mathrm{a}$ & $27.9 \mathrm{a}$ & $354.1 \mathrm{a}$ \\
\hline Class 3 & $14.2 \mathrm{ab}$ & $184.2 \mathrm{ab}$ & $25.3 \mathrm{a}$ & $304.4 \mathrm{ab}$ \\
\hline \multirow[t]{2}{*}{ CV \% } & 15 & 15 & 8 & 10 \\
\hline & \multicolumn{4}{|c|}{ Plug plants } \\
\hline Class 1 & $25.9 \mathrm{a}$ & $356.1 \mathrm{a}$ & $39.9 \mathrm{a}$ & $496.5 \mathrm{a}$ \\
\hline Class 2 & $25.7 \mathrm{a}$ & $353.5 \mathrm{a}$ & $39.8 \mathrm{a}$ & $505.6 \mathrm{a}$ \\
\hline Class 3 & $26.4 \mathrm{a}$ & $384.9 \mathrm{a}$ & $42.7 \mathrm{a}$ & $564.2 \mathrm{a}$ \\
\hline CV \% & 11 & 12 & 11 & 13 \\
\hline
\end{tabular}

"Means followed by same letter in column do not differ (Tukey, $p<0.05)$. Crown diameter classes in bare root transplants: Class 1: (3.0 to $5.0 \mathrm{~mm})$, class $2(5.6$ to $8 \mathrm{~mm})$ and class $3(>8 \mathrm{~mm})$ and in plug plants: Class $1(2.0$ to $3.9 \mathrm{~mm})$, class $2(4.0$ to $5.5 \mathrm{~mm})$ and class $3(5.5$ to $6.9 \mathrm{~mm}$ ). 
able shipping conditions and could hardly be compensate for grower's cultural practices.

The vigor of transplants can be related to the size of the assimilate pool. In bare root ones, this pool is the main energy source for the emission and growth of new roots to replace those damaged at digging or cut off before planting. Nevertheless, new roots are not immediately able to absorb water and nutrients and plants are susceptible to stress in the days after planting (Gautier et al., 2001). In the strawberry plant, this phenomenon may be stronger than in other species, because it is considered as having a slow root growth (Hennion and Veschambre, 1997). As a consequence, high vigor transplants have faster initial growth.

In plug transplants differences in crown diameter of runner tips were small and the vigor was similar at planting. In these transplants, the root system is embodied by substrate and root damage at planting is minimized. Thus, roots can absorb water and nutrient soon after planting, resulting in faster initial growth and higher early and total fruit yield (Hochmuth et al., 2001; Durner et al., 2002; Takeda and Hokanson, 2003). Higher plant growth was also recorded at the end of the experiment on plants from plug transplants and data confirm results reported by other authors (Durner, 1999; Bish et al., 2002; Larson and Ponce, 2002; Hochmuth et al., 2006a, b; Giménez et al., 2009).

In this study, runner tips were harvested and screened in three crown diameter classes before rooting, ranging from $2 \mathrm{~mm}$ (Class 1) to $7 \mathrm{~mm}$ (Class 3). Nevertheless, after 48 days of growth on the rooting bed, the crown diameter among classes did not differ. All tips reached an average crown diameter of $8.6 \mathrm{~mm}$, higher than the value set for high vigor transplants $(8 \mathrm{~mm})$ (Table 2$)$. These results can be explained by the dynamics of root and shoot growth. In this experiment, a growing bed was used for rooting, without physical limitations for root growth. This condition differs from trays used in the production of horticultural transplants. In trays, the cell volume can limit root growth, affecting also shoot growth (Andriolo et al., 2003; Andrews et al., 2006; Giménez et al., 2009). In our experiment, it may be possible that shoot growth was not limited by physical constraints on root growth. As a consequence, tip shoots grew in all crown diameter classes until leaf area competition for radiation took place. This situation is similar to that used to explain the relationship between leaf area index (LAI) and interception of photosynthetically active radiation (PAR) by crops. In this way, at the end of the rooting period all tips could reach similar crown diameters. A technological implication is that all runner tips could be used for producing commercial plug transplants by using this method.

\section{Conclusions}

Higher growth, development and fruit yield were obtained in plants from plug transplants. For bare root transplants, crown diameters higher than $5.1 \mathrm{~mm}$ can be used while for plug transplants the crown diameter of runner tips does not affect growth and fruit yield.

\section{Acknowledgements}

To Conselho Nacional de Desenvolvimento Científico e Tecnológico for financial support. To Coordenação de Aperfeiçoamento de Pessoal de Nível Superior for a fellowship.

\section{References}

Andrews, M.; Raven, J.A.; Lea, P.J.; Sprent, J.I. 2006. A role for shoot protein in shoot-rot dry matter allocation in higher plants. Annals of Botany 87: 3-10.

Andriolo, J.L.; Espíndola, M.C.; Estefanello, M. 2003. Growth and development of lettuce plants from transplants with different physiological ages. Ciência Rural 33:1-15. (in Portuguese, with abstract in English).

Antunes, L.E.C.; Duarte Filho, J. 2005. Strawberry production system. In: Santos, A.M.; Campos, A.D.; Medeiros, A.R.M.; Gomes, C.B.; Vendruscolo, C.T.; Cofcewicz, E.T.; Duarte Filho, J.; Madail, J.C.M.; Vendruscolo, J.L.S.; Fortes, J.F.; Reichert, L.J.; Salles, L.A.B.; Migliorini, L.C.; Antunes, L.E.C.; Wrege, M.S.; Mattos, M.L.T.; Santos, P.E.T.; Cantillano, R.F.F. System of production, 5. EMBRAPA CT, Pelotas, RS, Brazil. Available at: http:// sistemasdeproducao.cnptia.embrapa.br. [Accessed Sept. 14, 2009]. (in Portuguese).

Bish, E.B.; Cantliffe, D.J.; Chandler, C.K. 2002. Temperature conditioning and container size affect early season fruit yield of strawberry plug plants in a winter, annual hill production system. HortScience 37: 762-764.

Durner, E.F.; Poling, E.B.; Maas, J.L. 2002. Recent advances in strawberry plug transplant technology. Hort Technology 12: 545-550.

Durner, E.F. 1999. Winter greenhouse strawberry production using conditioned plug plants. HortScience 34: 615-616.

Gautier, H.; Guichard, S.; Tchamitchian, M. 2001. Modulation of competition between fruits and leaves by flower pruning and water fogging, and consequences on tomato leaf and fruit growth. Annals of Botany 88: 645-652.

Giménez, G.; Andriolo, J.L.; Janish, D.J.; Cocco, C.; Dal Picio, M. 2009. Cell size in trays for the production of strawberry plug transplants. Pesquisa Agropecuária Brasileira 44: 726-729.

Giménez, G.; Andriolo, J.L.; Janish, D.; Godoi, R. 2008a. Closed soilless growing system for producing strawberry bare root transplants and runner tips. Pesquisa Agropecuária Brasileira 43: 1757-1761.

Gimenez, G.; Andriolo, J.; Godoi, R. 2008b. Strawberry soilless cultivation. Ciência Rural 38: 273-279 (in Portuguese).

Giménez, G.; Vicente, E.; Manzzioni, A. 2003. The Strawberry Cultivar INIA Arazá. Instituto Nacional de Investigación Agropecuaria, Montevideo, UY. (Hoja de Divulgación, 83). (in Spanish).

Hennion, B.; Veschambre, D. 1997. The Strawberry. Production control. CTIFL, Paris. (in French).

Hochmuth, G.; Cantliffe, D.; Chandler, C.; Stanley, C.; Bish, E.; Waldo, E., Legard; D., Duval, J. 2006a. Fruiting responses and economics of containerized and bare root strawberry transplants established with different irrigation methods. Hort Technology 16: 205-210.

Hochmuth, G.; Cantliffe, D.; Chandler, C.; Stanley, C.; Bish, E.; Waldo, E., Legard; D., Duval., J. 2006b. Containerized strawberry transplants reduce establishment-period water use and enhance early growth and flowering compared with bare-root plants. HortTechnology 16: 46-54.

Hochmuth, G.; Chandler, C.; Stanley, C.; Legard, D.; Duval., J.; Waldo, E.; Cantliffe, D.; Bish, E.. 2001. Containerized transplants for establishing strawberry crops in Florida. HortScience 37: 443446.

Larson, K.D.; Ponce, E.E. 2002. Containerized strawberry transplants as a replacement for methyl bromide soil fumigation in California strawberry nurseries: final report; Sustainable Agriculture Research and Education Program. University of California, Davis, CA. USA. 
Meier, U.; Graf, H.; Hack, M.; Hess, M.; Kennel, W.; Klose, R.; Mappes, D.; Seipp, D.; Stauss, R.; Streif, J.; Van Den Boom, D. 1994. Phenological devel-feed is the pome fruit (Malus domestica Borkh. and Pyrus communis L.), the stone fruits (Prunus spp), the currant (Ribes species) and the strawberry (Fragaria $x$ ananassa Duch.). Nachrichtenbl Deutchland Pflanzenschutzd 46: 141-153. (in German).

Moreno, J.A. 1961. Climate of the Rio Grande do Sul. Department of Agriculture, Porto Alegre. RS, Brazil. (in Portuguese).

Nicola, S. 1998. Understanding root systems to improve seedling quality. Hort Technology 8: 544-549.
Oliveira, R.P.; Nino, A.F.P.; Scivittaro, W.B. 2005. Certified strawberry transplants: better production and high fruit quality. A Lavoura 108: 35-38. (in Portuguese).

Santos, A.M.; Medeiros, A.R.M. 2003. Strawberry production; fruits of the Brazil. 40ed. EMBRAPA Clima Temperado, Pelotas, RS, Brazil. (in Portuguese).

Takeda, F.; Hokanson S.C. 2003. Strawberry fruit and plug plant production in the greenhouse. Acta Horticulturae 626: 283-285.

Received April 05, 2010

Accepted October 04, 2010 